\title{
Human resource management systems for enterprise organizations: A review
}

\author{
Subhi R.M. Zeebaree ${ }^{1}$, Hanan M. Shukur ${ }^{2}$, Bzar Kh. Hussan ${ }^{3}$ \\ ${ }^{1}$ Duhok Polytechnic University, Duhok-Iraq, subhi.rafeeq@dpu.edu.krd \\ ${ }^{1}$ Tishk International University, Erbil-Iraq \\ ${ }^{2}$ Department of Information System Engineering, Erbil Polytechnique University, Iraq, hanan89md@ gmail.com \\ ${ }^{2}$ Al_Kitab University \\ ${ }^{3}$ Department of Information System Engineering, Erbil Polytechnique University, Iraq, dr_bzar@yahoo.com
}

\section{Article Info}

Received Feb 3, 2019

\section{Keyword:}

E-HRM

Information system

Human resource management

E-HRM adoption factors

\begin{abstract}
Human Resources HRs are one of the most important elements in the organizations, but it is difficult to manage a large number of human resources, especially in large companies. For this purpose, companies have tended to manage these resources taking advantages of the technology and the Internet. In this research, we will focus on human resources management in different companies and different countries and explore the factors that motivate companies to adopt Electronic Human Resource Management E-HRM as well as the factors that affect its adoption. The results showed that HRM plays a vital role in facilitating organizational processes, save cost and time, it also beneficial for competitive advantages. The findings also explored that E-HRM aspects and factors impact E-HRM adoption are varied from firm to another and from country to another. However, the companies moved towards adopting E-HRM because it mitigates the efforts of HR managers to take a decision.
\end{abstract}

\section{Corresponding Author:}

First Author,

Technical College of Informatics Akre,

Duhok Polytechnique University,

Scientific research and development center Nawroz University, Iraq.

subhi.rafeeq@dpu.edu.krd

\section{Introduction}

Human Resource (HR) is the most important element in any organization. It was presented as a modern management method in the 1960s[1]. Currently, human beings are considered assets rather than resources[2]. HR consists of administrators, employees, users, and staff. It's difficult to deal with huge numbers of HRs in organizations especially large organizations, therefore, it's crucial to manage HR in an organized way. Innovative companies must predict the environment changes and prepare for any domestic changes as strategic management [3]. Therefore, Human resource management (HRM) is considered the most important managerial aspects in firms' life[4]. HRM is defined as a workforce management system[5]. It is necessary to motivate HRs to increase competitive advantages of any organization[6]. It aims to maximize the productivity of the staff in order to achieve the strategic objectives of the company[7]. HRM is the task of the HR department in organizations which concerned with managing issues related to HR for instance recruitments, leaves, punishments and appreciations, staff information, and salary. Therefore, the HR department considered an accelerator of organization changes[6]. In all business organizations, the HR department represents the most significant part[8]. In order to make HRM adapt internal and external rapid changes in the 
environment, it has to make HRM more strategic thus, meeting the challenges of recent firmsGupta [9]. For this reason, the organization's trend towards merging processes and activities of HR with Information Technology (IT) i.e. computerized HRM which benefits from abilities of technology. Human Resource Information System (HRIS) means automating the Human Resource department[10]. It uses IT with HR systems and processes[5]. It is an element which aims to optimize HRM in organizations[6]. The HR practices have been developed and shifted from HRIS towards Electronic Human Resource Management (E-HRM) which means automating services for managers and employees[10]. It is obvious that advance in IT has changed the HR functions; it enhances information sharing, administrative efficiency, and decision making[11]. The first time when the term E-HRM emerged and used was in the 1990s, which refers to HR transactions via the Internet and other technologies[9]. Studies defined and termed E-HRM in various ways. It can be termed as 'online HRM', 'electronic HRM', 'web-based HRM', 'E-HRM', 'virtual HRM', 'digital HRM', 'computer-based HRM', 'HRIT' and 'HRIS'[10]. E-HRM is defined as 'the application of computers and telecommunication devices to collect, store, retrieve, and disseminate [HR] data for business purposes'[12]. Another definition of E-HRM is "adopting activities of HRM with the help of Intranet or Internet"[13]. The purpose of E-HRM is to provide information to employees and managers at any time and anywhere[9]. For this reason, E-HRM has been utilized in various sectors, it has been used by the healthcare sector as a web- based electronic hospital system (i.e. e-hospital)[14]. It has been applied by the education sector to provide services for both students and lecturers for learning purposes (i.e. E-Learning)[15]. It also has been utilized to facilitate managing student affairs electronically within university[16]. It has a positive influence on HRM services by enhancing the perceptions of managers and employees of HRM services, simplifying HRM processes, and providing accurate data[17]. Applying E-HRM systems make HR more flexible, strategic, and cost-effective, it also enhances decision-making, speed response time, reduces the efforts of administrators, increases productivity, and enhance client services[13]. Therefore this review paper focuses on Human Resource Management, HRM systems using the Internet and other technologies in order to clarify the benefits of applying such systems in organizations also demonstrates factors motivating the organizations to adopt E-HRM, factors which lead to the underutilized use of E-HRM and shows HRM practices in some countries.

\section{Literature Review}

Nowadays, many types of research make a point of managing Human Resources in companies because HR plays a vital role in achieving competitive advantages for organizations. Efficient HRM will increase productivity and enhance staffs' ability to respond to the organization's changes. Hence, this paper produces an aggregation study in this field to help the enterprise organizations how utilizing the HR in efficient form with as minimum as possible different costs including human efforts.

Kitimaporn Choochote and Kitsiri Chochiang [8], brought to the light research to study the pattern of E-HRM of hotels business in Phuket. The findings of the study on E-HRM of hotels explored that job recruitment, employee engagement, organizational file structure, idea and creativity exchanges, and the assessment system has been used and applied with various rates. On the other hand, the salary system, welfare system, career development, and learning and training system has not prepared to apply. The results also revealed that 10 percent of basic organizational information management system agreed to use E-HRM while 90 percent failed to apply E-HRM.

Ma and Ye [13], studied the aspects of EHRM which are EHRM definition (managing HR using Internet), EHRM role (eliminates "HR middleman", provides strategic planning in the HR organization), EHRM types (operational, relational and transformational EHRM), effectiveness of E-HRM, factors impacting utility and determinants of attitude towards E-HRM (user satisfaction, clarify EHRM goals, ease of use system, social influence, user support, and perceived usefulness). The study aims to facilitate understanding EHRM more systematically and comprehensively, so it can be a reference for HRM researchers.

Another important issue is HR allocation; it can be done via team formation in order to maximize the utilizing of skills. It means to put the right person in the right position. Wu, Jiang [1], presented a mechanism of human resource allocation as multiple teams to satisfy the demand for skills efficiently. The human resources are represented as agents; the tasks represent the work that the human resources have to finish. Firstly, the 
mechanism assigns the agents to the tasks, where agents with greater contribution than others will be chosen as members of the group to finish the task. Secondly, after group formation, the contributed skills will be reassigned according to the skills requirements of the tasks with the least cost, which is beneficial for maximizing the efficiency of the team and utilizing skills. The mechanism model is shown in Fig1.

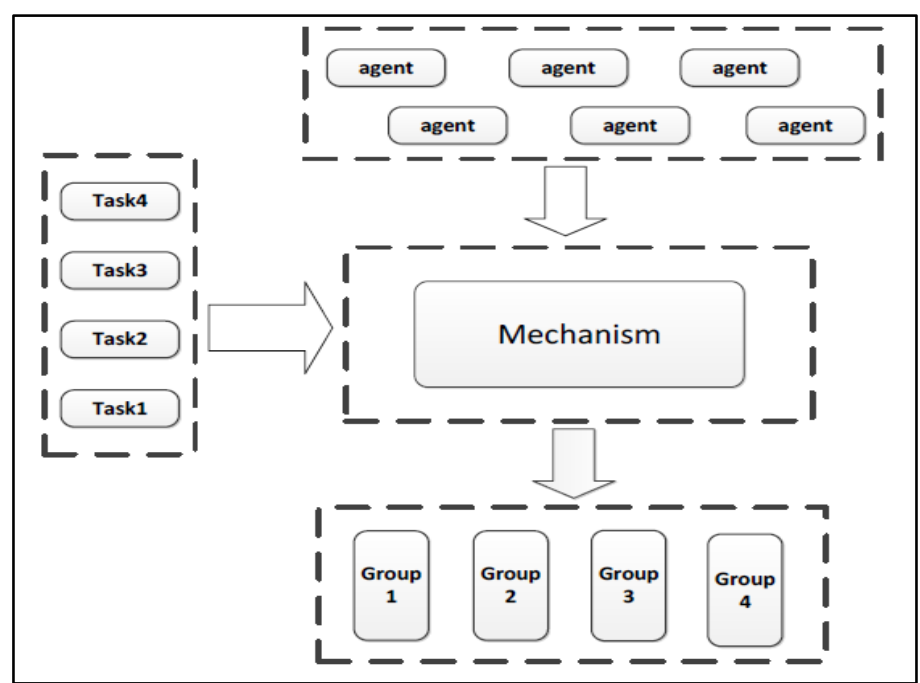

Fig1. The mechanism model[1].

HRM aspects and practices are different from company to another according to company size or its ownership. Čech, Yao [4], presented a survey about analyzing HRM practices for 67 Chinese manufacturing firms. The survey covered key aspects of HRM like HR department setting, a number of HR employees, HR planning, HR recruitment and employment, and employees training and development. The results of a survey showed that HRM aspects are different according to the company's ownership and company size. The survey found that: 1) large and medium-sized firms involve independent human resource departments while small companies do not. 2) Employee number and firm ownership type have a vital impact on HRs rate. 3) HR strategy and planning are identified for most companies. 4) Regarding the recruitment sources, firms preferred internal sources, while more than half companies select both external and internal sources for the leader position. 5) Most firms have training (on-site or off-site training) and development plan.

Li, Samolejová [6], carried out a survey to compare HRM practices between Chinese and Czech firms. The survey explored the following: 1) Internal recruitment is preferred in Czech companies while external recruitment is preferred in Chinese companies. Regarding the selection method, both countries use one-to-one interviews. 2) Training and development vary in terms of training types and expenses for training, Chinese firms prefer on-the-job training; in contrast, Czech companies choose off-the-job training. 3) Performance appraisal varies in terms of participants of appraisal and appraisal methods. Czech firms choose supervisor as the main appraiser while Chinese firms choose peer, self, and subordinate as an appraiser. 4) Compensation differs in terms of salary influencing factors and pays determination (industry/individual) level.

Another research focused on the factors or reasons motivating the organizations to adopt E-HR and observed the impact of using E-HR in companies. Masum, Alam [18], presented a conceptual model to explore the determinants or factors motivating the organizations to adopt electronic human resource management (EHRM) in Bangladesh. The result of structural equation modeling (SEM) found that perceived cost, perceived compatibility, top management support, centralization, organizational culture, government support, and IT vendor support are the significant factors to the adoption of E-HRM. The SEM findings also suggested that industry pressure, perceived complexity, and relative advantage do not have any influence on the organizational adoption of E-HRM.

Different electronic HRM systems, web-based applications, and models have been designed according to the company's requirements. Hakke, Mante [5], designed Resource Management Group Portal (RMGPortal) to appoint right employee with the right skill to suitable requirement client. The system manages internal and 
external resources, thus reducing the efforts of managers and generating reports. A wireframe is designed to solve user experience problems and provide a good visual design. The RMGPortal functional overview is shown in Fig2. In RMGPoratl, the requirement comes from the client through Delivery Partner (DP), (Vendor Service Unit) VSU or Client Manager and Profiles come from Internal, RMG (Resource Management Group) or TAG to RMGPortal. All profiles are stored in the RMG database. The user login and request from multiple functionalities like Request View, Profile View, Allocation, BGV initiation, VSU report, RGS Creation, SOW status, upload billing vital report, External hiring, Profile tracking to get daily reports.

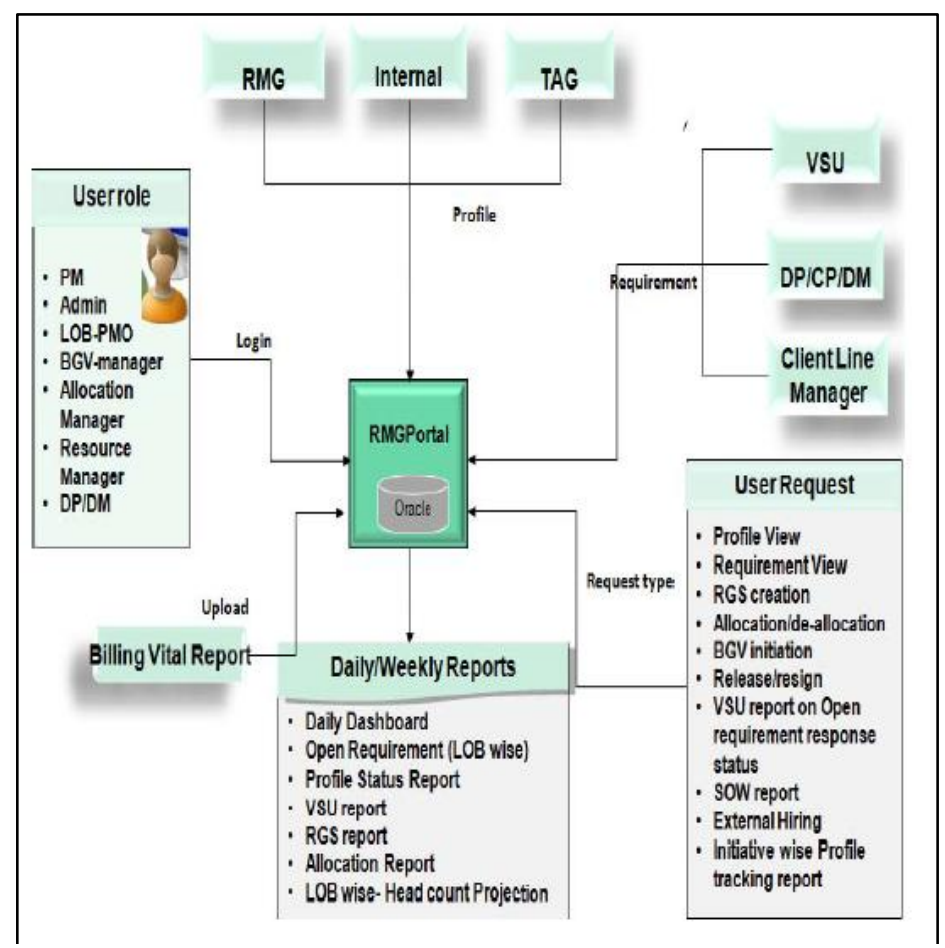

Fig2. RMG Portal functional overview[5].

Hao [19], proposed an employee competence model for JLIT company, to manage human resources in the transition period of Mobile Internet era. The model was designed based on a questionnaire survey and the iceberg theory. The proposed model consists of six factors "customer-oriented, innovation, competition, cooperation, team consciousness and continuous learning" which are required for JLIT's employees, see Fig3. Using iceberg theory, it's necessary to manage the problem from the bottom before controlling it from the peak of the iceberg. This paper aims to be as a reference for innovation strategies of HRM in the transition period of Mobile Internet.

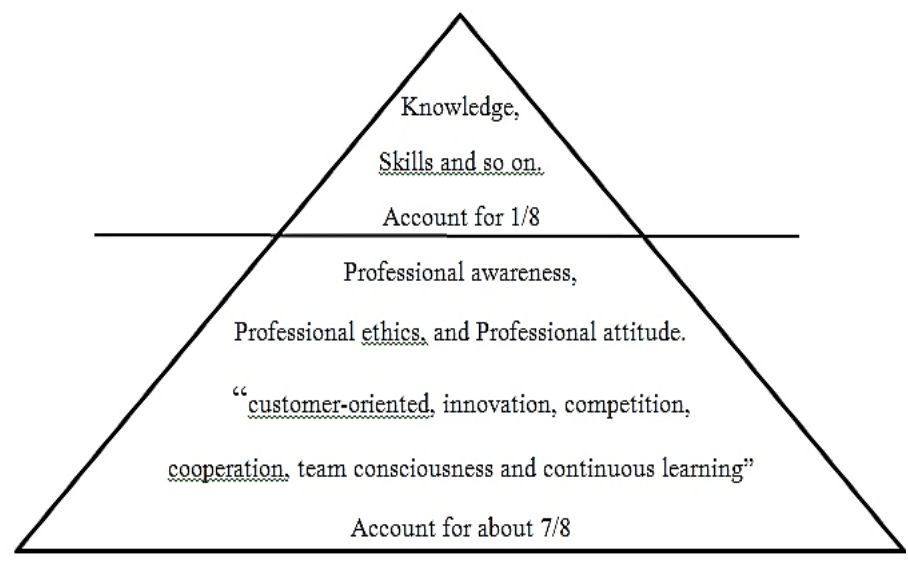

Fig3. Employee competency model of JLLT Company in the Mobile Internet[19].

Weeramanthrie, Thilakumara [2], proposed a unique web application called (ARROW) which aims to predict 
employee turnover in firms. ARROW system is designed to fulfill the gap between managers' ability to understand the current employees' behavior and the employees' behavior in past, present, and future in the organization. The first step of the proposed system is generating a questionnaire survey according to the user/organization ideas. The second step is hypothesis testing to analyze gathered data of survey then generate attractive reports for decision makers. These two steps are to analyze the current employee situation. The third step is to analyze past employee behavior by identifying hidden patterns from a given data set using predictive data mining technique. Finally, identifying employees' performance range (low or high performance), to help the managers to predict employees' future performance. This system can serve worldwide human resource researchers and organizations.

Electronic HR might face some obstacles which make its usage unutilized perfectly because of some factors, therefore many studies focused on factors impacting utility and determinants of attitude towards E-HRM in different countries. Bondarouk, Parry [10], reviewed four decades of researches on E-HRM adoption and consequences. The summary of this research showed that factors influencing E-HRM adoption can be categories into three areas which are: 1) Technology (system integration, system usefulness, data integrity, and using external HRIS software versus in-house development), 2) Organization (data access, planning, and project management traditions, organizational characteristics, capabilities and resources, and security and privacy), 3) People (user acceptance, top management support, communication and collaboration between units, leadership and culture, and HR skills and expertise) . It can be defined as "TOP" framework. It also showed that consequences of E-HRM are classified into three types: 1) Operational (effectiveness and efficiency gains, and cost savings), 2) Relational (service improvements, improved communication, and cooperation), 3) Transformational (consistency of HR practices). The comprehensive review also found that E-HRM goals changed to the strategic reorientation of human resource departments and improved HR services instead of efficiency. In the same time, consequences changed to relational and then transformational outcomes instead of operational effects.

Randle, Coleman [20], revealed the external factors which lead to the underutilized use of human resource information system (HRIS) in South African universities. The first factor is organizational ethics which determines who can access the information of HRIS, thus affects individuals' decisions to use the system. The second factor is organizational politics it is political issues which have a strong influence on HRIS usage. The last factor is an organizational culture like performance improvement, training, and development, employment equity; organizational culture represents a critical factor to underutilize the system. Therefore they proposed a conceptual model that motivates the employees to utilize the system correctly, thus the effective use of HRIS in the universities. The model involves the following components: employee citizenship, organizational trust and commitment, psychological well-being, individual differences, job satisfaction, and social environment which motivate the employee to use the system efficiently.

HR capacity must be available during the implementation and reconfiguration of health information software(HIS) platform to overcome problems of HRs capacities challenges in developing countries, for this reason the research of Msiska [21], proposed a shared pool of staff or talent from various stakeholders as a strategy to reduce the challenges of human resource capacities in growing countries like Malawi, which contributes in deploying and fully leveraging open source health information software(HIS) platforms. Evaluating the efficacy, challenges (availability of pooled talent) and factors (information dependencies, mutual interests, and effective cost) of suggested strategy are identified by tracking and evaluating occurrences of the staff pooling during the implementation and reconfiguration of HIS in Malawi.

Some companies with multi-sites suffer from complexity to manage constrained mobility of HR like recruitment.

Tkatek, Abdoun [22], presented an expert system to enhance the constrained mobility of human resources like staff recruitment and redeployment. The proposed system done by applying a genetic algorithm aims to increase productivity and enhance the performance. Practical examples have been applied to the system in order to obtain an optimal binary matrix of recruitment and reassigning employees. Fig4 shows recruitment matrix generated by the proposed expert system. 


\section{$\left(\begin{array}{lll|lll}1 & 1 & 1 & 1 & 0 & 0 \\ 1 & 0 & 0 & 0 & 0 & 0 \\ 1 & 1 & 0 & 0 & 0 & 0 \\ 1 & 1 & 1 & 1 & 0 & 0\end{array}\right)$}

Fig4. Recruitment matrix generated by the proposed expert system[22].

As shown in the Fig4, the value 1 represents recruited and assigned candidate, while a candidate who is not selected to recruit is represented by value 0 .

Vinogradova, Andreeva [23], described a corporate information system which is used to optimize HRM of the industrial economic complex in Russian. Analyzing the key tendencies of development of corporate information systems showed that automation of management should be imposed on the debugged structure of HRM. The most efficient method to adapt dynamical changes of the marketplace is a transition to sliding planning instead of periodic planning; in such planning method, the enterprise takes into consideration both internal and external factors influencing the manufacturing process which has competitive advantages to predict possible methods of development. This economic planning method acts as an effective tool to assess the requirements of the start software.

Gupta [9], identified the reasons to adopt E-HR in Greece, studied success determinant for E-HR adoption, and observed the impact of using E-HR. The study showed that adopting E-HR is beneficial for communication, it facilitates the organizational processes like recruitment, facilitates decision making, provides strategic HRM roles by enhancing the quality of services and saving cost and time management. The key success determinant of adopting e-HR is organizational culture, technical awareness, and human and computer resources. The e-HR has a vital impact on developing skills of organizational staff.

\section{Discussion}

From previously mentioned literature reviews, it is obvious that diverse researches have been focused on HRM because of its importance. The current study showed that HRM practices, a percentage of utilizing EHRM, determinants or factors motivating the organizations to adopt E-HRM, and the factors impact the adoption of E-HRM efficiently are different from one company/country to another. Each study has certain objectives, methodology, and advantages. Table1 show comparison among these researches. However, our opinion of proposed HRM system which can satisfy requirements of enterprise organization is based on some semaphores: Logical data modeling, Data Flow Modeling, Entity Event Modeling. The system should pass three stages: Feasibility study, Investigation of the current environment, Business system options, Requirements specification, Technical system options, Logical design, and Physical design.

Table1. Comparison among researches of

\begin{tabular}{|c|c|c|c|c|c|}
\hline Author & Objective & Methodology & Advantage & $\begin{array}{l}\text { Software/ } \\
\text { Technique } \\
\text { / Tools }\end{array}$ & $\begin{array}{l}\text { Case Study/ } \\
\text { Location }\end{array}$ \\
\hline $\begin{array}{c}\text { Msiska } \\
{[21]}\end{array}$ & $\begin{array}{l}\text { Reduce the } \\
\text { challenges of HR } \\
\text { capacities by } \\
\text { ensuring the } \\
\text { availability of } \\
\text { talents. }\end{array}$ & $\begin{array}{l}\text { Tracking and evaluating } \\
\text { the occurrences of staff } \\
\text { during the } \\
\text { implementation of the } \\
\text { software platform. }\end{array}$ & $\begin{array}{l}\text { Utilizing the full } \\
\text { benefits of open } \\
\text { source HIS platforms. }\end{array}$ & ----- & Malawi \\
\hline $\begin{array}{c}\mathrm{Wu}, \\
\text { Jiang [1] }\end{array}$ & $\begin{array}{l}\text { Satisfying the } \\
\text { demand for skills } \\
\text { efficiently. }\end{array}$ & $\begin{array}{l}\text { a mechanism of HR } \\
\text { allocation as multiple } \\
\text { teams by assigning }\end{array}$ & $\begin{array}{l}\text { Beneficial for } \\
\text { maximizing the } \\
\text { efficiency of the team }\end{array}$ & ----- & ----- \\
\hline
\end{tabular}




\begin{tabular}{|c|c|c|c|c|c|}
\hline & & $\begin{array}{l}\text { suitable agents to the task } \\
\text { and least cost. }\end{array}$ & and utilizing skills. & & \\
\hline $\begin{array}{l}\text { Tkatek, } \\
\text { Abdoun } \\
\text { [22] }\end{array}$ & $\begin{array}{l}\text { An expert system } \\
\text { to enhance the } \\
\text { constrained } \\
\text { mobility of HRs. }\end{array}$ & $\begin{array}{l}\text { Applying the genetic } \\
\text { algorithm to obtain an } \\
\text { optimal binary matrix of } \\
\text { recruitment and } \\
\text { reassigning employees. }\end{array}$ & $\begin{array}{l}\text { Increase productivity } \\
\text { and enhance } \\
\text { performance. }\end{array}$ & Matlab & ----- \\
\hline $\begin{array}{l}\text { Čech, } \\
\text { Yao [4] }\end{array}$ & $\begin{array}{c}\text { Explore the } \\
\text { characteristics of } \\
\text { HRM. }\end{array}$ & $\begin{array}{l}\text { Carry out a survey to } \\
\text { analyze HRM practices } \\
\text { like HR department } \\
\text { setting, a number of HR } \\
\text { employees, HR planning, } \\
\text { HR recruitment and } \\
\text { employment, and } \\
\text { employees training and } \\
\text { development. }\end{array}$ & $\begin{array}{l}\text { It is a valuable survey } \\
\text { for comparison with } \\
\text { Czech companies } \\
\text { results. }\end{array}$ & ----- & $\begin{array}{l}\text { Chinese } \\
\text { manufacturing } \\
\text { firms. }\end{array}$ \\
\hline $\begin{array}{l}\text { Li, } \\
\text { Samolej } \\
\text { ová [6] }\end{array}$ & $\begin{array}{l}\text { Highlight the } \\
\text { most significant } \\
\text { differences in } \\
\text { HRM aspects } \\
\text { between Chinese } \\
\text { and Czech firms. }\end{array}$ & $\begin{array}{l}\text { Carry out a survey to } \\
\text { compare HRM practices } \\
\text { between Chinese and } \\
\text { Czech firms. }\end{array}$ & $\begin{array}{l}\text { Clarify the major } \\
\text { differences of HRM } \\
\text { practices. }\end{array}$ & SPSS 13.0 & $\begin{array}{l}\text { Chinese and } \\
\text { Czech firms. }\end{array}$ \\
\hline $\begin{array}{l}\text { Randle, } \\
\text { Colema } \\
\mathrm{n}[20]\end{array}$ & $\begin{array}{l}\text { Reveal the } \\
\text { external factors } \\
\text { which lead to the } \\
\text { underutilized use } \\
\text { of HRIS. }\end{array}$ & $\begin{array}{l}\text { Design a conceptual } \\
\text { theoretical model that } \\
\text { motivates the employees } \\
\text { to utilize the HRIS } \\
\text { correctly and efficiently. }\end{array}$ & $\begin{array}{l}\text { The outcome of this } \\
\text { research may help HR } \\
\text { practitioners and } \\
\text { managers to prompt } \\
\text { and enhance the } \\
\text { effective use of HRIS. }\end{array}$ & $\begin{array}{l}\text { The } \\
\text { factors are } \\
\text { modeled } \\
\text { using } \\
\text { Structural } \\
\text { Equation } \\
\text { Modelling } \\
\text { (SEM). }\end{array}$ & $\begin{array}{c}\text { South African } \\
\text { universities. }\end{array}$ \\
\hline $\begin{array}{l}\text { Bondaro } \\
\text { uk, } \\
\text { Parry } \\
{[10]}\end{array}$ & $\begin{array}{l}\text { Find out the } \\
\text { factors } \\
\text { influencing E- } \\
\text { HRM adoption } \\
\text { and } \\
\text { consequences. }\end{array}$ & $\begin{array}{l}\text { Review four decades of } \\
\text { researches of E-HRM } \\
\text { adoption and } \\
\text { consequences. }\end{array}$ & $\begin{array}{l}\text { Provide an integrative } \\
\text { framework and a } \\
\text { summary as support } \\
\text { for future research. }\end{array}$ & $\begin{array}{c}\text { A } \\
\text { database } \\
\text { search of } \\
\text { Scopus } \\
\text { and Web } \\
\text { of } \\
\text { Science. }\end{array}$ & ----- \\
\hline $\begin{array}{l}\text { Ma and } \\
\text { Ye [13] }\end{array}$ & $\begin{array}{c}\text { Facilitate } \\
\text { understanding E- } \\
\text { HRM more } \\
\text { systematically } \\
\text { and } \\
\text { comprehensively. }\end{array}$ & $\begin{array}{l}\text { Study the aspects of E- } \\
\text { HRM like E-HRM } \\
\text { definition, its role, types, } \\
\text { factors impacting utility } \\
\text { E-HRM, and E-HRM } \\
\text { goals. }\end{array}$ & $\begin{array}{l}\text { This study can be a } \\
\text { reference for HRM } \\
\text { researchers. }\end{array}$ & ----- & ----- \\
\hline $\begin{array}{l}\text { Vinogra } \\
\text { dova, } \\
\text { Andreev } \\
\text { a [23] }\end{array}$ & $\begin{array}{l}\text { Optimize HRM } \\
\text { using corporate } \\
\text { information } \\
\text { system. }\end{array}$ & $\begin{array}{c}\text { Analyze the key } \\
\text { tendencies of } \\
\text { development of corporate } \\
\text { information systems and } \\
\text { describe the internal and } \\
\text { external factors } \\
\text { influencing the } \\
\text { manufacturing process. }\end{array}$ & $\begin{array}{l}\text { This economic } \\
\text { planning method acts } \\
\text { as an effective tool to } \\
\text { assess the } \\
\text { requirements of the } \\
\text { start software. }\end{array}$ & ----- & Russian. \\
\hline $\begin{array}{l}\text { Masum, } \\
\text { Alam } \\
{[18]}\end{array}$ & $\begin{array}{l}\text { Detect the major } \\
\text { factors of E- } \\
\text { HRM adoption. }\end{array}$ & $\begin{array}{l}\text { A conceptual model to } \\
\text { explore the determinants } \\
\text { motivating the }\end{array}$ & $\begin{array}{l}\text { Findings of this } \\
\text { research will assist } \\
\text { decision-makers to }\end{array}$ & $\begin{array}{c}\text { Structural } \\
\text { Equation } \\
\text { Modelling }\end{array}$ & Bangladesh. \\
\hline
\end{tabular}




\begin{tabular}{|c|c|c|c|c|c|}
\hline & & $\begin{array}{c}\text { organizations to adopt E- } \\
\text { HRM }\end{array}$ & $\begin{array}{l}\text { take a decision on } \\
\text { adopting E-HRM. }\end{array}$ & (SEM). & \\
\hline $\begin{array}{c}\text { Gupta } \\
{[9]}\end{array}$ & $\begin{array}{c}\text { Find out the } \\
\text { reasons to adopt } \\
\text { E-HR, clarify } \\
\text { success } \\
\text { determinant for } \\
\text { E-HR adoption, } \\
\text { and observed the } \\
\text { impact of using } \\
\text { E-HR. }\end{array}$ & $\begin{array}{c}\text { combination of } \\
\text { quantitative and } \\
\text { qualitative methods } \\
\text { which include groups and } \\
\text { questionnaire. }\end{array}$ & $\begin{array}{l}\text { The results of this } \\
\text { paper can be extended } \\
\text { to different countries } \\
\text { to share the same } \\
\text { features as Greece in } \\
\text { the context of using E- } \\
\text { HRM. }\end{array}$ & ----- & Greece. \\
\hline $\begin{array}{l}\text { Kitimap } \\
\text { orn } \\
\text { Chooch } \\
\text { ote and } \\
\text { Kitsiri } \\
\text { Chochia } \\
\text { ng [8] }\end{array}$ & $\begin{array}{l}\text { Study the pattern } \\
\text { of E-HRM in } \\
\text { hotels business. }\end{array}$ & $\begin{array}{c}\text { Using qualitative } \\
\text { methods and collect data } \\
\text { from in-depth interviews } \\
\text { with HR managers and } \\
\text { personnel. }\end{array}$ & $\begin{array}{l}\text { Highlight different } \\
\text { patterns of E-HRM. } \\
\text { Identify basic } \\
\text { organizational } \\
\text { information } \\
\text { management system } \\
\text { which adopts E-HRM } \\
\text { and others not adopt it. }\end{array}$ & ----- & $\begin{array}{l}\text { Hotels } \\
\text { business in } \\
\text { Phuket. }\end{array}$ \\
\hline $\begin{array}{l}\text { Weeram } \\
\text { anthrie, } \\
\text { Thilaku } \\
\text { mara [2] }\end{array}$ & $\begin{array}{l}\text { Fulfill the gap } \\
\text { between } \\
\text { managers' ability } \\
\text { to understand the } \\
\text { current } \\
\text { employees' } \\
\text { behavior and the } \\
\text { employees' } \\
\text { behavior in past, } \\
\text { present, and } \\
\text { future in the } \\
\text { organization. }\end{array}$ & $\begin{array}{l}\text { ARROW system to } \\
\text { analyze the current } \\
\text { employee situation via } \\
\text { generating a } \\
\text { questionnaire survey, } \\
\text { then hypothesis testing to } \\
\text { analyze gathered data of } \\
\text { survey then generate } \\
\text { attractive reports for } \\
\text { decision makers. After } \\
\text { that, analyze past } \\
\text { employee behavior by } \\
\text { identifying hidden } \\
\text { patterns from a given data } \\
\text { set. }\end{array}$ & $\begin{array}{l}\text { This system can serve } \\
\text { worldwide human } \\
\text { resource researchers } \\
\text { and organizations. } \\
\text { identifying } \\
\text { employees' } \\
\text { performance range } \\
\text { (low or high } \\
\text { performance), to help } \\
\text { the managers to } \\
\text { predict employees' } \\
\text { future performance. }\end{array}$ & $\begin{array}{l}\text { Data } \\
\text { mining } \\
\text { technique } \\
\text { (clustering } \\
\text { k-mean } \\
\text { technique) }\end{array}$ & Sri Lanka. \\
\hline $\begin{array}{l}\text { Hakke, } \\
\text { Mante } \\
{[5]}\end{array}$ & $\begin{array}{l}\text { Fulfill the } \\
\text { requirements of } \\
\text { the clients. }\end{array}$ & $\begin{array}{c}\text { Design Resource } \\
\text { Management Group } \\
\text { Portal (RMGPortal) to a } \\
\text { appoint right employee } \\
\text { with the right skill to } \\
\text { suitable requirement } \\
\text { client. }\end{array}$ & $\begin{array}{l}\text { Reduce the efforts of } \\
\text { managers and generate } \\
\text { reports. }\end{array}$ & $\begin{array}{l}\text { HTML5, } \\
\text { CSS3, } \\
\text { Hibernate, } \\
\text { Spring } \\
\text { framewor } \\
\text { k and } \\
\text { JavaScript } \\
\end{array}$ & ----- \\
\hline Нао [19] & $\begin{array}{l}\text { Enhance the } \\
\text { efficiency of HRs } \\
\text { in the transition } \\
\text { period of Mobile } \\
\text { Internet era. }\end{array}$ & $\begin{array}{c}\text { Design employee } \\
\text { competence model based } \\
\text { on a questionnaire survey } \\
\text { and iceberg theory. }\end{array}$ & $\begin{array}{l}\text { This paper aims to be } \\
\text { as a reference for } \\
\text { innovation strategies } \\
\text { of HRM in the } \\
\text { transition period of } \\
\text { Mobile Internet. }\end{array}$ & ----- & $\begin{array}{c}\text { JLIT } \\
\text { company. }\end{array}$ \\
\hline
\end{tabular}

\section{Conclusions}

The findings of our review paper explored that HRM is a very important issue to be studied and discussed. Internet and other technologies have a great role in managing human resources, therefore companies moved towards adopting E-HRM because it mitigates the efforts of HR managers to take a decision, save cost and time required for management, facilitate organizational processes, enhance quality of services, developing 
skills of organizational staff, enhance the constrained mobility of HRs like staff recruitment and redeployment, it is beneficial for competitive advantages, it also beneficial for communication. But multiple factors impact E-HRM adoption such as organizational ethics, organizational politics, organizational culture, technology, people, social influence, these factors are different from company to another. The HRM practices also are different according to the size and ownership of the organization, selection/ interview method, training and development, performance appraisal, and recruitment sources (internal or external HR sources). As a future work in this field, we suggest that the designers of enterprise organization systems should take in consideration the improved approaches of how to get active usability of human resource management. Hence, to reach the ability of: monitoring, tracking the development, feedback suggestions and maintaining steps of enterprise system life cycle process.

\section{References}

[1] J. Wu, Y. Jiang, and J. Zhu, "Human Resource Allocation Combined with Team Formation," in 2016 International Conference on Computational Intelligence and Applications (ICCIA), 2016, pp. 67-71.

[2] T. T. Weeramanthrie, C. N. Thilakumara, K. N. A. C. Wijesiri, N. I. Fernando, S. Thelijjagoda, and A. Gamage, "ARROW: A web-based employee turnover analysis tool for effective human resource management in large-scale organizations," in 2017 National Information Technology Conference (NITC), 2017, pp. 136-140.

[3] N. V. Lashmanova, E. S. Fedorova, and M. A. Kossukhina, "Human resources management strategy on an innovative company: Competence approach," in 2016 IEEE V Forum Strategic Partnership of Universities and Enterprises of Hi-Tech Branches (Science. Education. Innovations), 2016, pp. 54-56.

[4] M. Čech, W. Yao, A. Samolejová, J. Li, and P. Wicher, "Human Resource Management in Chinese manufacturing companies," Perspectives in Science, vol. 7, pp. 6-9, 2016/03/01/ 2016.

[5] P. G. Hakke, R. V. Mante, and P. N. Chatur, "Digital channel for Resource Management Group Portal," in 2016 2nd International Conference on Advances in Electrical, Electronics, Information, Communication and Bio-Informatics (AEEICB), 2016, pp. 720-723.

[6] J. Li, A. Samolejová, M. Čech, and M. Lampa, "Comparison of HRM practices between Chinese and Czech companies," Perspectives in Science, vol. 7, pp. 2-5, 2016/03/01/ 2016.

[7] J. Raszka and L. Jamroż, "Reducing human resources in management of information technology (IT) projects," in 2015 8th International Conference on Human System Interaction (HSI), 2015, pp. 115121.

[8] Kitimaporn Choochote and Kitsiri Chochiang, "Electronic Human Resource Management (e-HRM) of Hotel Business in Phuket,", International Journal of Advanced Computer Science and Applications,, vol. 6, 2015.

[9] D. P. Gupta, "The Adoption of Human Resources Online and the Role of Human Resources Management: the Facts Observed in Greece," Journal of HR, Organizational Behaviour \&amp; Entrepreneurship Development, pp. 6-20\%V 2, 2018-06-15 2018.

[10] T. Bondarouk, E. Parry, and E. Furtmueller, "Electronic HRM: four decades of research on adoption and consequences," The International Journal of Human Resource Management, vol. 28, pp. 98-131, 2017/01/02 2017.

[11] L. Song and J. Li, "Building HR Information Modeling and Risk Management: A Bayesian Networks Approach," 2nd IEEE Advanced Information Management,Communicates,Electronic and Automation Control Conference (IMCEC), Xi'an, 2018, pp. 1-2004., 2018

[12] D. L. Stone, Deadrick, D. L., Lukaszewski, K. M., \& Johnson, R., "The influence of technology on the future of human resource management. ," Human Resource Management Review, vol. 25, pp. 216-231, 2015.

[13] L. Ma and M. Ye, "The Role of Electronic Human Resource Management in Contemporary Human Resource Management," Open Journal of Social Sciences, vol. 03No.04, p. 8, 2015.

[14] M. A. a. S. Zeebaree, "Design and Implementation an e-Hospital System at Kurdistan," Kurdistan Journal of Applied Research, vol. 2 No.3, pp. 80-86, Aug. 2017.

[15] A. Z. Mohsin Abdulazeez, Subhi \& Ihsan Abdullah, Abdulrahman., "Design and Implementation of Electronic Learning System for Duhok Polytechnic University. ," Academic Journal of Nawroz University (AJNU), vol. vol.7, 2018. 
[16] M. M. A. Mohammed Sadeeq, Adnan., "Design and Implementation of Electronic Student Affairs System," Academic Journal of Nawroz University (AJNU), vol. vol.7, 2018.

[17] T. Bondarouk, R. Harms, and D. Lepak, "Does e-HRM lead to better HRM service?," The International Journal of Human Resource Management, vol. 28, pp. 1332-1362, 2017/05/15 2017.

[18] A. K. M. Masum, M. G. R. Alam, M. S. Alam, and M. A. K. Azad, "Adopting factors of electronic human resource management: Evidence from Bangladesh," in 2016 International Conference on Innovations in Science, Engineering and Technology (ICISET), 2016, pp. 1-4.

[19] Y. Hao, "Innovation Strategies of Mobile Operator's HRM Model in Transition Period of Mobile Internet," in 2016 International Symposium on Computer, Consumer and Control (IS3C), 2016, pp. 57-60.

[20] O. A. Randle, A. Coleman, and R. Kekwaletswe, "Towards a motivational based model for effective use of human resource information system in South African Universities," in 2017 International Conference on Information Society (i-Society), 2017, pp. 61-67.

[21] B. Msiska, "Pooling human resources needed to leverage open source health information software platforms in developing countries," in 2017 IST-Africa Week Conference (IST-Africa), 2017, pp. 1-8.

[22] S. Tkatek, O. Abdoun, and J. Abouchabaka, "An expert system for a constrained mobility management of human resources," in 2017 International Colloquium on Logistics and Supply Chain Management (LOGISTIQUA), 2017, pp. 53-58.

[23] E. Y. Vinogradova, S. L. Andreeva, A. V. Babkin, and A. I. Galimova, "Corporate information system - Element of efficient human resources management of the industrial-economic complex," in 2017 IEEE VI Forum Strategic Partnership of Universities and Enterprises of Hi-Tech Branches (Science. Education. Innovations) (SPUE), 2017, pp. 63-66.

[24] P. P. Sengupta, M. Sinha, and U P. Dutta, "Economic and environmental performances in manufacturing industries: A comparative study", Periodicals of Engineering and Natural Sciences, Vol. 7, No. 1, June 2019, pp.99-108.

[25] L. U. Ozolina, A. Jansone, I. Magazeina, and D. Barute, "Technology enhanced learning in teachers' professional development", Periodicals of Engineering and Natural Sciences, Vol. 7, No. 1, June 2019, pp.216-221. 